\title{
THE CIRCUMSTANCES AND CONTRIBUTIVE FACTORS OF ESTIMATE AND SELECTION OF THE INFORMATIONAL SITUATIONAL RESOURCES OF ECONOMIC INFORMATICS SYSTEMS
}

\author{
Tudor Ştefan Leahu \\ Free International University of Moldova, 2012, Vlaicu Pârcălab str., 52, \\ Chişinău, Republic of Moldova, leahu.ts@ mail.ru
}

\begin{abstract}
The created situation, the factors, what contributing at it, are characterized. The necessity of return and revision of elaborative stage of constitution of the economic informatics systems (E.Ic.S.) it's substantiated. Also, the idea of opposite order of the concept of invention, elaboration, production and application of the informatics resources, as well as, and the concept of them estimation and selection are formulated.
\end{abstract}

Keywords: estimate, selection, informational situational (informative, descriptive) resources, economic informatics systems, conceptual criteria.

Introduction: In conditions of the approach completely informational society, except the problems of the invention, production and using the informatics means and technological methods in any sphere of the human activities, of decisive importance disposing the rational selection, what directly affecting the working of the E.Ic.S. That is why, off the scientificaly positions and economical raison, alwais itself soliciting the such works, which precede herself the projection and implementation of these systems, as the establishing of the composition and elaboration of the criteria of selection of informational resources.

\section{A. The circumstances and contributive factors}

Today and in predictable perspective the rational organization and efficient working of unitary economic informational process are conditioned of through application of the advanced informatics means and methods in the named sphere. Also, it's awared what the systemic (in interconnection and interaction) approach and achievement of these two components (means and methods) are finded your accomplishment in the shape of economic informatics systems (E.I. S.).

Among other resources of vital functional importance are those informational, without wich not may be achivied the E.I . .S.. These resources disposing of the very much diverse composition, excessive volumes and works, wich need to effect a one complexe of preparatory works of projection content.

As a motivation of justification of created situation are the directly physical acces of the user at the informatics technical means, in first hand, at the computer, them relatively cheap cost, "simplified" of the procedures of programming, because that them becoming more "friendly", the progressive "reduction" of informatics technologies at the manual (according to content, composition and succession of them realization, but not and according to the modality them execution), a.s.o. The necessity to return and review the elaborative stage of the E. Ic. S. is based not only on the scientific awareness of them establishment and functioning, but on the household raison. The existing economic informational medium, that is characterized by fragmented informatics covering, complex variety of the informatics means and methods, the lasts to being explaining for the same neglect of the systemic approach of achievement of the sphere in cause.

Following further on such motivation, it may be 
establish that the conception of the invention, elaboration, production and application of informatics means and methods require the inversion of the orientation comparatively with the existing outlook.

The essence of this inversion itself reducing to the fact that the technical means and technological methods must having elaborated and implemented in basis of the qualitative (composition, structure) and quantitative (volume of activities, information, etc.) parameters of the sphere of them application.

B. The selection of the methods of the organizing of economic situational information

At once, those most elaborated, more conceptually and unusual achieved in informatics practice, are methods of organization data on the physical space of computer memory. Such situation oneself explained of the circumstances of need of to keeping of data values which are required by the particularities of economic informational problems. So, in dependence of the physical environment of the computer memory, all the methods of the physical packing of data can be systematized into two groups - the methods one's own for physical space of the operative (internal) memory and the methods own for the milieu of the external memory.

Table 1. The interconnections and interactions of proceedings of the data physical packing on the operative memory (O.M.) and external memory (E.M.), depending of the type of data structures (D.S.) *)

\begin{tabular}{|c|c|c|c|c|c|c|}
\hline \multirow{4}{*}{$\begin{array}{l}\mathrm{NN} \\
\text { ord }\end{array}$} & \multirow{4}{*}{$\begin{array}{l}\text { Type of the data } \\
\text { structures }\end{array}$} & \multicolumn{5}{|c|}{ Physical packing proceedings } \\
\hline & & \multicolumn{3}{|c|}{ On operative memory (O.M.) } & \multicolumn{2}{|c|}{ On external memory (E.M.) } \\
\hline & & \multirow{2}{*}{ he method } & \multicolumn{2}{|c|}{ Prganized areas } & \multirow{2}{*}{ The method } & \multirow{2}{*}{$\begin{array}{l}\text { Organized } \\
\text { areas }\end{array}$} \\
\hline & & & on O.M. & on E.M. & & \\
\hline 1 & $\begin{array}{l}\text { The succesive } \\
\text { data structures - } \\
\text { S.D.S. }\end{array}$ & $S$ & - & R.A. & $S$ & D.A. \\
\hline \multirow[b]{2}{*}{2} & \multirow{2}{*}{$\begin{array}{l}\text { The row data } \\
\text { structures } \\
\text { R.D.S. }\end{array}$} & \multirow{2}{*}{ C } & \multirow{2}{*}{ L.A. } & \multirow{2}{*}{ R.A. } & $S$ & D.A. \\
\hline & & & & & $\mathrm{D}$ & D.A. \\
\hline \multirow{3}{*}{3} & \multirow{3}{*}{$\begin{array}{l}\text { The compound } \\
\text { data list structures } \\
\text { - C.D.L.S. }\end{array}$} & \multirow{3}{*}{$\mathrm{N}$} & \multirow{3}{*}{ L.A. } & \multirow{3}{*}{ R.A. } & I.S. & D.A. \\
\hline & & & & & $\mathrm{R}$. & I.A., D.A.,O.A. \\
\hline & & & & & $S$ & D.A. \\
\hline \multirow{6}{*}{4} & \multirow{6}{*}{$\begin{array}{lr}\text { The } & \text { tabular } \\
\text { (matrixly) } & \text { data } \\
\text { structures } & - \\
\text { T.(M.)D.S. } & \end{array}$} & \multirow{2}{*}{ B.R.Z. } & \multirow{2}{*}{ A.T.C. } & \multirow{2}{*}{$\begin{array}{l}\text { A.O.V.,A.O.C., } \\
\text { A.K.R. }\end{array}$} & $S$ & D.A. \\
\hline & & & & & I.S. & R.A.,D.A.,O.A. \\
\hline & & \multirow{2}{*}{ L.P. } & \multirow{2}{*}{ L.P.A. } & \multirow{2}{*}{$\begin{array}{l}\text { A.O.V.,A.O.C., } \\
\text { A.K.R. }\end{array}$} & $S$ & D.A. \\
\hline & & & & & I.S. & I.A.,D.A.,O.A. \\
\hline & & \multirow{2}{*}{ C.I. } & \multirow{2}{*}{ A.C.I. } & \multirow{2}{*}{$\begin{array}{l}\text { O.V.A., O.C.A. } \\
\text { K.R.A. }\end{array}$} & $S$ & D.A. \\
\hline & & & & & I.S & I.A.,D.A.,O.A. \\
\hline \multirow{2}{*}{5} & \multirow{2}{*}{$\begin{array}{l}\text { The arborescent } \\
\text { data structures - } \\
\text { A.D.S. }\end{array}$} & S.(D.)A. & $\begin{array}{l}\text { L.A. } \\
\text { (R.A.A.) }\end{array}$ & R.A. (E.A) & I.S. & I.A.,D.A.,O.A.. \\
\hline & & T.N. & $\begin{array}{l}\text { L.A. } \\
\text { (N.E.A.) }\end{array}$ & R.A. (E.A.) & I.S. & I.A.,D.A.,O.A.. \\
\hline
\end{tabular}

*) The organized areas:
Taking in consideration the fact that the packing of data on the operative memory (O.M.) not can be achieved without of the organization of certain areas in the external memory (E.M.), 
itself requiring the necessity to establishing the interconnections and interactions between of the both groups of above mentioned methods. Moreover, herself taking into account not only the functional compatibility, but also the posibilities of these interdependences, regarding the ensurance of promptness of data manipulation in base of the concordant joing of the in cause methods.Starting from the cleared up resons, the possible interconnection and interaction between the physical methods of data packing on the space of the internal and external millieu of computer memory are presented in table 1[1,286-292;4,150-162].

The presented in this table concordance between the methods and physical proceedings of data packing on the O.M. and E.M. spaces are more efficacious in cause of correctly selection of data structures for any informational entity of the respective problemOn the basis of the particularities of transformation of functional economic informational entities, on the conceptual level was determined the orientative composition of the data structures indicated for the any group of the problems of economic management undersystem and presented in the table 2. [1,290-292; 4,153-154]

\section{The estimation and selection of economic situational data structures.}

Are known many criteria of estimation of data economic structures, on the basis of which tacking place them selection, however, fundamental itself though the nexts:

1) the promptness of forming (systematization, sorting, arranging) of the data structures;

2) the rational (thrifty) level of utilization of memory space ;

3) the comform and promptness of the correction of data structure

4) the promptness of the recovering of the structural elements ;

5) the general criterion $[1 ; 4]$.

Table 2. The conceptual selection of the data structures convients for the informational entities of the any group of problems of economic management undersystems.

\begin{tabular}{|l|l|l|l|}
\hline $\begin{array}{l}\text { Undersystem of } \\
\text { economic } \\
\text { management }\end{array}$ & $\begin{array}{l}\text { The group of the } \\
\text { problems of undersystem } \\
\text { of economic management }\end{array}$ & $\begin{array}{l}\text { The categories of } \\
\text { involved information } \\
\text { in the solving group } \\
\text { of problems }\end{array}$ & $\begin{array}{l}\text { The data structures } \\
\text { selected for } \\
\text { informatics } \\
\text { organization of } \\
\text { categories of the } \\
\text { information }\end{array}$ \\
\hline $\begin{array}{l}\text { The rate- } \\
\text { settings and } \\
\text { regulation of the } \\
\text { economic } \\
\text { material } \\
\text { activities } \\
\text { (R.S.E.M.A.) }\end{array}$ & $\begin{array}{l}\text { The calculation of the } \\
\text { values of primary rates }\end{array}$ & $\begin{array}{l}\text { The calculation of the } \\
\text { applicabilities } \\
\text { measurement data }\end{array}$ & $\begin{array}{l}\text { The succesive data } \\
\text { structures }\end{array}$ \\
\cline { 2 - 4 } & $\begin{array}{l}\text { The calculation of the } \\
\text { applicabilities }\end{array}$ & $\begin{array}{l}\text { The arborescent, } \\
\text { reticular data } \\
\text { structures }\end{array}$ \\
\hline $\begin{array}{l}\text { The forecast } \\
\text { (F.P.) and } \\
\text { current } \\
\text { foreseeing } \\
\text { planning } \\
\text { (C.P.) }\end{array}$ & $\begin{array}{l}\text { The calculation of the } \\
\text { values of forecast } \\
\text { foreseeing indicators of } \\
\text { the evolution of economic } \\
\text { material activities. } \\
\text { The calculation of the } \\
\text { values of indicators of } \\
\text { another compartments of } \\
\text { current planning }\end{array}$ & $\begin{array}{l}\text { The primary rates } \\
\text { technical, economic, } \\
\text { social information. } \\
\text { strative (account } \\
\text { statement) data, the } \\
\text { values of the current } \\
\text { planning, economic } \\
\text { analysis and rate- } \\
\text { setting indicators }\end{array}$ & $\begin{array}{l}\text { The arborescent, } \\
\text { reticular data } \\
\text { structures }\end{array}$ \\
$\begin{array}{l}\text { The reticular data } \\
\text { structures } \\
\text { The compound data } \\
\text { list structures } \\
\text { structures } \\
\text { The compound data } \\
\text { list structures }\end{array}$ \\
\hline
\end{tabular}




\begin{tabular}{|c|c|c|c|}
\hline $\begin{array}{l}\text { The operative } \\
\text { planning and } \\
\text { directing of } \\
\text { economic } \\
\text { material } \\
\text { activities } \\
\text { (O.P.D.E.M.A.) }\end{array}$ & $\begin{array}{l}\text { The calculation of the } \\
\text { values of indicators of } \\
\text { operative planning of } \\
\text { evolution of economic } \\
\text { material activities. } \\
\text { The calculation of the } \\
\text { values of indicators of } \\
\text { another compartments of } \\
\text { operative planning }\end{array}$ & $\begin{array}{l}\text { The financial- } \\
\text { administrativ } \\
\text { (account-statement), } \\
\text { evidence operative } \\
\text { data, the indicators of } \\
\text { economic operative } \\
\text { analysis, the rate- } \\
\text { setting indicators } \\
\text { The evidence general } \\
\text { indicators }\end{array}$ & $\begin{array}{l}\text { The compound data } \\
\text { list structures } \\
\text { The reticular data } \\
\text { structures }\end{array}$ \\
\hline $\begin{array}{l}\text { The evidence } \\
\text { and financial } \\
\text { administration } \\
\text { (E.F.A.) }\end{array}$ & $\begin{array}{l}\text { The problems of } \\
\text { operative evidence. } \\
\text { The problems of book- } \\
\text { keeping. } \\
\text { The problems of the } \\
\text { financial administration } \\
\text { (account) }\end{array}$ & $\begin{array}{l}\text { The evidence general } \\
\text { indicators. } \\
\text { The indicators of } \\
\text { estimation and } \\
\text { hauling time of the } \\
\text { economic resources. } \\
\text { The indicators of } \\
\text { account (financial } \\
\text { administration) }\end{array}$ & $\begin{array}{l}\text { The successive data } \\
\text { structures. } \\
\text { The arborescent, } \\
\text { tabular (matrixly) } \\
\text { data structures }\end{array}$ \\
\hline
\end{tabular}

a) on the O.M. space : L.A. - the list area, I.D.A. - the indicators area, A.T.C. - the area of the table of concordance, L.P.A. - the logical plate area, A.C.I. - the area of the couples of the indexis, R.(D.)A.A. - the relation (dart) addresses of area, N.E.A. - the area of element numbers ;

b) on the E.M. space : R.A. - the recordings area, O.V.A. - the objects vectors area, O.C.A. - the object characteristics area, K.R.A. - the keeping rows area, E.A. - the elements area, D.A. - the data area, I.A. - the indexis area, R.A. - the references area (the relation adress of D.A.), D.C.A. - data collections area, D.A. - the outrunning area ,T.N. - " trace notation", R.A.A.- relation addresses of area. The methods of the physical packing of data : on O.M. space : $\mathrm{S}$ - succesiv, $\mathrm{L}$ - in chain, $\mathrm{N}$ - in nest, $\mathrm{K}$ - in knot, B.R.Z. - the basic and reserve zone, L.P. logical plate, C.I.- couples of addresses; on E.M.: I.S.- indexed- successive, O.A.- objects area. The enumerated criteria are caracterized by certain values, which are calculated in accordance with the respectively formula [1, 290 300; 4, 170 - 175].

The estimation of any data structure on the basis only of one at the essential enumerated criteria is unilateral, and therefore, erroneus, because each criterion characterizing such structure in accordance with the value exclusively of one them parameter. Moreover, some criteria are unaccepatable for any data structures. That is why with a view to generalizing them values can be applied the synthesizer of weighing, assignement of concrete values for them is enough dificult, if not impossible. So started from the principle that any of the criteria is not we given priority, assigning each a special parameter - points.

The calculus of the size of this parameter is bazed on the such concept, in concordance with the value of the criterion is all the diminished as, the structure is more its concordant. If some structures have the equal values of one and the same criteria, then all are assigned the equal points. For other structures such value may be determinated through comparing of the them values with the value of the comparable structure. Through the addition of the every peculiar values to obtain the generalizing value of the structure [1,302-303].

The results of the estimation of data structures on the basis of generalizing criterion may be concluding under of following table : 
Table 3. The example of the generalizing criteria of estimation of the data structure

\begin{tabular}{|l|l|l|l|l|l|l|}
\hline \multirow{2}{*}{$\begin{array}{l}\text { NN } \\
\text { ord }\end{array}$} & $\begin{array}{l}\text { The varietes of data } \\
\text { structures }\end{array}$ & \begin{tabular}{l} 
The criteria of the estimation \\
\cline { 3 - 7 } \\
Time ormation \\
(sorting)
\end{tabular} & $\begin{array}{l}\text { The suppli- } \\
\text { mentary } \\
\text { space of } \\
\text { memory }\end{array}$ & $\begin{array}{l}\text { The of } \\
\text { Time } \\
\text { recovering }\end{array}$ & $\begin{array}{l}\text { Time of } \\
\text { correction }\end{array}$ & \\
\hline 1 & Succesive structure & 2,5 & 1 & 1 & 13 & 17,5 \\
\hline 2 & $\begin{array}{l}\text { In succesion one- } \\
\text { directional } \\
\text { structure }\end{array}$ & 4 & 8,5 & 7,5 & 22,5 \\
\hline 3 & $\begin{array}{l}\text { In succesion two- } \\
\text { directional } \\
\text { structure }\end{array}$ & 2,5 & 5 & 8,5 & 9 & 27,5 \\
\hline
\end{tabular}

The generalizing estimation of the data structures can tacking place and through comparing of the couples of such structures on the basis of calculation of values of two them criteria.

The calculation of the values of estimation criteria of the data structures for them further organization and informational or structural processing is need tacking place after «junction » of functional organizing of the informational entities with the possible variants of informatics them organization and processing. Therefore, the determination of the variety of data structure, which is concordant with concrete informational entity is necessary to effectuated in following succession:

the determination of the composition of the functional informational entities, of them structures, methods of organization and transformative procedures proper them ;

the selection for them informatics achievement of possible data structure, proceedings (methods) of physical packing on the espace of the opertaive and external memories, as well as of respectively informatics transformational procedures ;

the calculation of the estimation criteria of data structure, them physical methods of packing and transformation procedures already selected (at the second stage).

D. The presentation, estimation and selection of transformation of the values of situational economic data

At present for the examination and understooding of processing process exercized concerning data values oneself applieding various algorithms, which after forme of the presentation are systematized in such three essential groups - oral (textual), mathematics (under forme of formula) and graphics (under forme of various schemes). At the moment, the last group is on of the most developped and in combination with mathematical methods of formalizing in the most detalied and clearly mod presents the logical sequence of solving problems. The most spreads ways of graphical describing of processes of the solving of economic informative problems found them realization in the form of block diagram, diagram of programmed lines and scheme of the operators. Still are known and applied the modul schemes and informational-technological schemes. After volume of the presentation of in cause processes, the last cathegorie of such schemes (of operators) is one of the most economical, but they can help determine on the general level only the scheme of the succesion of achievement of procedures and operations data processing, which is insufficient for that goal.

Very much as initially the informatics technique prevalent achievementing the calculation processing, in graphically shape itself presenting only this cathegory of operations. At present the such technique automatic fullfilling the informational and structural processing, in examination schemes them are comprised incompletly and fragmentally, that more through are presented in informational-technological schemes. But, and here not are presented the mathematical algorithms, its being replacing of the certain programme moduls, what creating obstacles in the revealing of calculable content of problem, of going and succession of it solving 
stages. From his raison, such schemes are resembling more with informational models of solving of the informativ content problems. Therefore, such cathegory of schemes solicit the perfecting, which himself reduced to them completion with all necessary of calcul and incalcul procedures data processing, as well as with respectively identifiers of the informational units.

But, in created situation not always himself following the principal - obtaining of qualitative informational products.

In such cause the criteria of estimation of the transformative procedures and operations perhaps expressed in values of the indicators of quality of informational products[1,304-306; 2 , 93-132;4, 94-106].

\section{Conclusions}

The necessity of the selection of informatics resources starting from them domain of application, is founded for the logic of scientific approach and the careful management raison.

Such selection contributing at the prolongation of the working period of informatics components; requiring of starting at the informational domain towards informatics resources.

Anticipated of the selection itself soliciting the certain preparatory works,.

In accordance with the cleared up concept so that imposing the selection primary the methods and procedees of organizing, structuring and transformation of informational resources.

It's necessary for these resources to elaborate or making in evident the new collections of criteria for them selection.

It imposing the accomplishing of the such selection in complex, the decisive remaining the informational resources.

References

[1] Tudor Leahu Organizarea, structurarea şi transformarea informaţiilor sistemului managerial economic . Monografie. Chişinău, C.E.P. USM, 2009, 431p.

[2] Tudor Leahu, Larisa Hâncu Bazele sistemelor informatice economice. Chişinău, C.E.P. USM, 2005, 388 p.

[3] T.Şt. Leahu Despre o metodă de determinare a valorilor parametrilor cantitativi ai informaţiilor economice în baza algoritmilor matematici. Materialele Conferinţei internaţionale, vol.I. Chişinău, 2004 D.E.P. al ASEM, pp.56-59.

[4] F.S.Leahu. The economic information : organizing, structuring and transformation. Chisinev,Contabilservis, 1990, 221 p.(rus) 